\title{
Plant microfossils in human dental calculus from Nemrik 9, a Pre-Pottery Neolithic site in Northern Iraq
}

\author{
Linda Scott Cummings ${ }^{1} \cdot$ Chad Yost $^{1,2} \cdot$ Arkadiusz Soltysiak $^{3}$
}

Received: 24 June 2015 / Accepted: 5 October 2016 / Published online: 24 October 2016

(C) The Author(s) 2016. This article is published with open access at Springerlink.com

\begin{abstract}
Samples of dental calculus were taken from 11 human individuals buried at Nemrik 9, a Pre-Pottery Neolithic site in Northern Iraq. All of them represented the time span of ca. 9100-8600 BP. In total, 95 microfossils were retrieved from these samples, including 70 phytoliths, 9 starch granules or clusters of starch, 3 pollens, and 1 xylem fragment. Most microfossils could be attributed to $\mathrm{C}_{3}$ cool season cereals, most likely wheat and barley, which is consistent with previous knowledge about the composition of crops in early farming communities living in the Fertile Crescent. In addition, three phytoliths and one starch granule typical of $\mathrm{C}_{4}$ warm season grasses were recovered including one subangular and faceted starch granule, which might derive from a native grass, but is not diagnostic of any genus. Prior to assigning diagnostic status to this starch, exhaustive reference work on native grass seeds is necessary. The presence of one Phragmites phytolith suggests non-alimentary processing of reeds using teeth or perhaps using the stem of this grass as a toothbrush or toothpick.
\end{abstract}

Keywords Phytoliths - Starch granules - Cereals - Fertile Crescent $\cdot$ Beginning of agriculture

Arkadiusz Soltysiak

a.soltysiak@uw.edu.pl

1 PaleoResearch Institute, 2675 Youngfield St, Golden, CO 80401, USA

2 Geosciences, University of Arizona, 1040 4th St, Tucson, AZ 85721, USA

3 Department of Bioarchaeology, Institute of Archaeology, University of Warsaw, ul. Krakowskie Przedmieście 26/28,

00-927 Warsaw, Poland

\section{Introduction}

Analysis of plant microfossils retrieved from dental calculus provides direct insight into diet and sometimes also into non-alimentary tooth use in ancient human populations (Cummings and Magennis 1997; Henry and Piperno 2008). This method has been used successfully in research on diet and subsistence in Neanderthals (Henry et al. 2011, 2014; Hardy et al. 2012) and in several Holocene human populations around the world (e.g., Dudgeon and Tromp 2012; Mickleburgh and Pagán-Jiménez 2012), including also one Bronze Age site in Syria (Henry and Piperno 2008). Surprisingly, no analysis of plant microfossils embedded in human dental calculus has been conducted so far using samples from archaeological sites dated to the beginning of agriculture in the Fertile Crescent, although data on direct plant consumption would be very useful in reconstructions of processes that led to transformation of wild grass gatherers into plant cultivators.

Here, we present the results of research on phytoliths, starches, and other plant microfossils recovered from several samples of dental calculus retrieved from Pre-Pottery Neolithic (PPN) human skeletons buried at Nemrik 9, which is an important site of early farmers located on the upper Tigris in the hilly area of Northern Mesopotamia (Fig. 1). The site was excavated between 1985 and 1989 by a Polish team directed by Stefan K. Kozłowski. Many layers of occupation dated to the PPN A and B were found, including a series of rounded houses and a small cemetery (Kozłowski 2002). Nemrik 9, together with Zawi Chemi, Qermez Dere, M'lefaat, and Tell Magzalia, represents the eastern part of the Fertile Crescent, which has been much less investigated than Levantine or Anatolian areas of early plant cultivation in the Near East (Willcox 2012). 
Fig. 1 Map of Mesopotamia showing the location of Nemrik 9

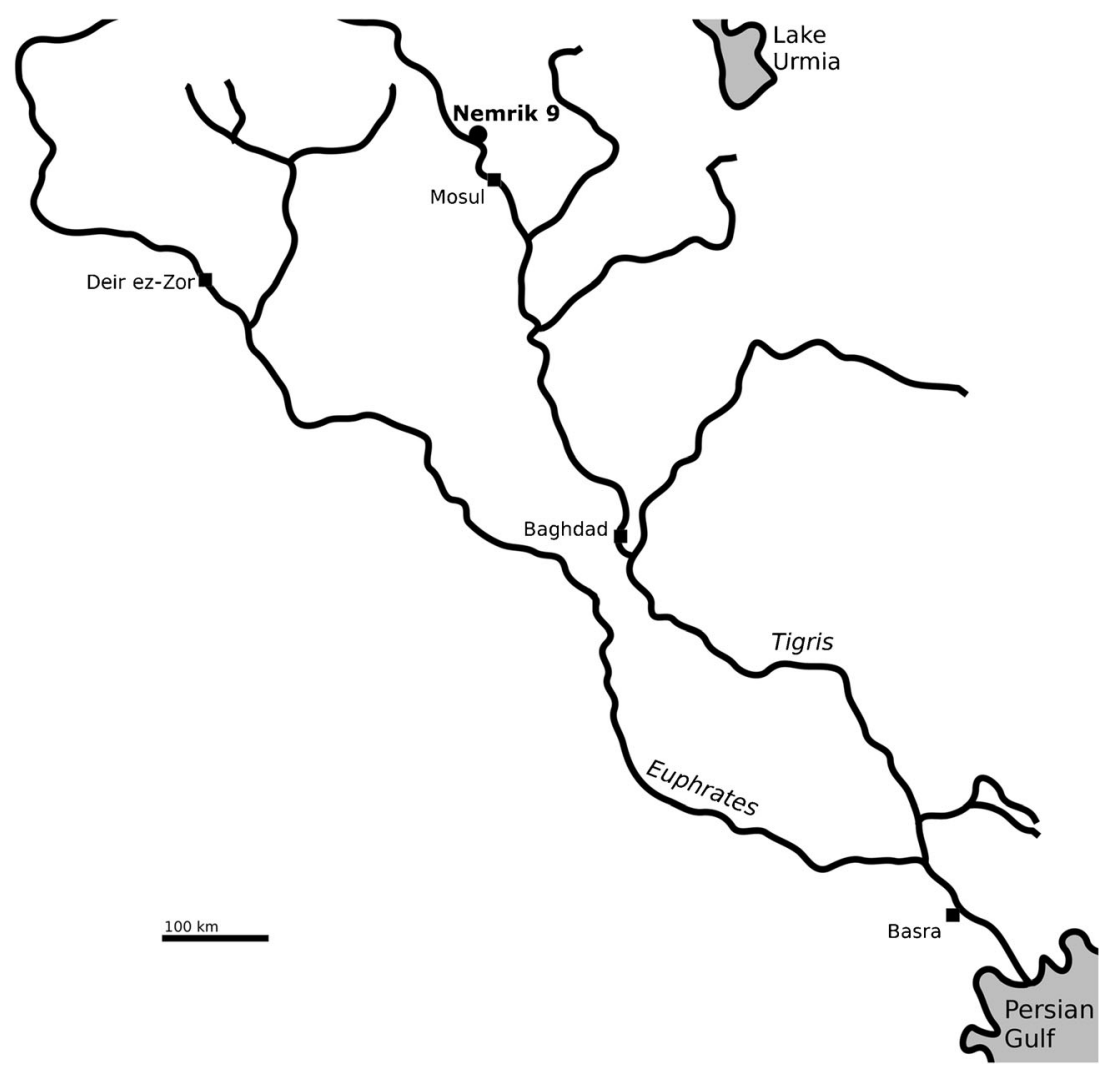

There are only very limited data on plants that were potentially consumed at Nemrik 9. Mark Nesbitt conducted very brief research on charred plant remains and found mainly legumes (bitter vetch, lentils, peas), wild pistachio, and some wild grass grains (Kozłowski 1989, 2002). Legumes also were most abundant among charred plant remains at nearby sites of Qermez Dere and M'lefaat where no evidence of domesticated cereals was noted, although small seeded grasses were more abundant than at PPNA sites from the Levantine and Anatolian parts of the Fertile Crescent (Savard et al. 2006). Among grasses identified at both these sites were barley (Hordeum cf. spontaneum, Hordeum murinum), einkorn (Triticum boeoticum), and goatgrass (Aegilops cylindrical tauschii/speltoides) (Savard et al. 2003, 2006).

Research on plant microfossils in dental calculus provides a different perspective than analysis of charred plant macroremains. Legumes and fruits produce fewer phytoliths than do grasses (Tsartsidou et al. 2007), and, in many cases, grass taxa may be better recognized using phytoliths than using macroremains (Piperno 1988). Therefore, analysis of phytoliths may provide better insight into grass products consumed by inhabitants of Nemrik 9. On the other hand, starch granules are less distinctive than phytoliths (Torrence and Barton 2006) and the risk of contamination by modern starches is considered high by some (Crowther et al. 2014), so their interpretative potential may be limited. Occasionally, pollen and fragments of plant tissue also may be embedded into calculus, representing both edible and non-edible plants in the local environment.

\section{Material and methods}

During archaeological excavations at Nemrik 9, remains of at least 94 human individuals were found. Most skeletons had been buried at a small cemetery (phase IVb, before $8600 \mathrm{BP}$ ) and beneath floors of houses, usually in multiple secondary commingled deposits (phase IIIb, c. 9100-8900 BP). In many cases, trabecular bone was almost completely destroyed and innominate bones and crania were strongly fragmented, so reliable sex and age-at-death assessments were possible only in a few cases (Sołtysiak et al. 2015). Dental calculus was present on many teeth, although usually in rather small quantities. In total, 24 teeth from 11 individuals, including 9 individuals representing phase $\mathrm{IIIb}$ and 2 individuals representing phase IVb, were selected for the current analysis (see Table 1).

Teeth were sent to PaleoResearch Institute (PRI) in Golden, $\mathrm{CO}$, which is a professional laboratory for exploration of archaeobotanical samples of all types. PRI maintains extensive reference collections for pollen, phytoliths, starches, seeds and other plant reproductive structures, and charcoal from around the world. These reference collections were consulted for identification of the remains recovered. The International Code for Starch Nomenclature was used to describe these starches.

Each individual tooth was placed in an ultrasonic water bath and sonicated for approximately $30 \mathrm{~s}$ to remove extraneous dirt and debris, including any contaminants that might have been introduced during excavation or curation. After these 
Table 1 Provenience data for samples from Nemrik 9

\begin{tabular}{|c|c|c|c|c|c|c|c|c|}
\hline \multirow[t]{2}{*}{ ID } & \multirow[t]{2}{*}{ Grave } & \multirow[t]{2}{*}{ House } & \multirow[t]{2}{*}{ Phase } & \multicolumn{4}{|c|}{ Number of teeth per category } & \multirow{2}{*}{$\begin{array}{l}\text { Calculus } \\
\text { amount (mg) }\end{array}$} \\
\hline & & & & I & $\mathrm{C}$ & $P$ & M & \\
\hline $\mathrm{NK} / 1891$ & 5 & & $\mathrm{IVb}$ & 2 & & & & 7.0 \\
\hline $\mathrm{NK} / 2335$ & 14 & & $\mathrm{IVb}$ & & & & 2 & 38.8 \\
\hline $\mathrm{NK} / 2393$ & 26 & $2 \mathrm{~A}$ & IIIb & 1 & & 1 & & 7.9 \\
\hline $\mathrm{NK} / 2394$ & 26 & $2 \mathrm{~A}$ & IIIb & & & 1 & & 8.1 \\
\hline $\mathrm{NK} / 2423$ & 26 & $2 \mathrm{~A}$ & IIIb & & 1 & 2 & 1 & 16.5 \\
\hline $\mathrm{NK} / 2437$ & 26 & $2 \mathrm{~A}$ & IIIb & & & 1 & & 11.2 \\
\hline $\mathrm{NK} / 2512$ & 31 & $1 \mathrm{~A}$ & IIIb & & & 2 & & 2.0 \\
\hline $\mathrm{NK} / 2638$ & 34 & $1 \mathrm{~A}$ & IIIb & 1 & & & & 1.8 \\
\hline $\mathrm{NK} / 2732$ & 40 & $1 \mathrm{~A}$ & IIIb & & & 1 & & 1.5 \\
\hline $\mathrm{NK} / 2801$ & 39 & $2 \mathrm{~A}$ & IIIb & 1 & & & & 8.8 \\
\hline $\mathrm{NK} / 3341$ & B & $4 \mathrm{~A}$ & IIIb & 2 & & 3 & 2 & 25.0 \\
\hline
\end{tabular}

contaminants had been removed, calculus from each tooth was flaked-off using a dental pick and collected in a plastic $1.5-\mathrm{ml}$ centrifuge tube. When a single sample contained multiple teeth, the calculi from all of the teeth were combined into one tube. One milliliter of $10 \%$ hydrochloric acid $(\mathrm{HCl})$ was added to each tube to dissolve the calculus and release any pollen, phytolith, and starch granules that were present. After $45 \mathrm{~min}$, each calculus sample had dissolved thoroughly and was rinsed with reverse osmosis deionized (RODI) water and centrifuged for $5 \mathrm{~min}$ at $3000 \mathrm{rpm}$. This rinse procedure was repeated three more times with RODI, followed by a final rinse with alcohol.

All of the remaining material from each sample was then placed on a microscope slide, dried, and mounted in immersion oil to facilitate rotating pollen, phytolith, and starches. The entire slide was scanned at $\times 500$ using standard and cross-polarized light microscopy. Micrographs were taken using a Nikon CoolPix 4500 camera mounted on a phototube. Observed microremains were identified using standard protocols (Piperno 1988; Torrence and Barton 2006) and the PRI reference library. The discrimination between wheat and barley phytoliths was based on data published by Rosen (1992), and the criteria for starch granule cooking were taken from Henry et al. (2009). Starches were identified using their 3D morphology. Size is less a factor in identification and is not discussed for starches here, since starches vary considerably in size in seeds, grains, and tubers. Starch counts employed the convention from pollen analysis of recording each cluster as a single item, resulting in reporting clusters, whether they included 2, 10, or more starches, as a single starch on the table.

Although Crowther et al. (2014) make a case for risk that starches of cereals, which are widely used in modern industry, may contaminate ancient samples, the method of extraction used for these samples minimized any potential of contamination. Hands were thoroughly washed prior to handling samples. Washing the teeth that bear calculus prior to removing the calculus prevents introduction of extraneous starch into ancient samples, as it removes any starches and other bits that have accumulated during sample collection and/or curation. These methods were followed with the express purpose of preventing contamination from modern starch. No food is allowed into the laboratory. Gloves used in our laboratory are purchased as "powder free," and individual gloves are checked from each box prior to their use in the lab to be certain that we are not introducing starch contamination. When starches have been found on gloves (this test is carried out in a different room), they are usually either subangular to angular or spherical, but not lenticular, indicating that the starch industry uses cornstarch rather than wheat or barley starch in the manufacture of latex gloves. In addition, contamination from other samples in the lab is not likely due to our lab procedures. When starch contamination at the point of making slides, for instance, from the cover slips, has been observed, the starches are in a predictable pattern such as distributed around the edges of the cover slips. This distribution was not observed in these samples. Therefore, we believe that we can rule out contamination as the origin of these starches. Further, in several samples, recovery of lenticular starches typical of wheat and barley was accompanied by recovery of phytoliths indicating wheat and/or barley, which strengthens the interpretation that the starches reflect diet and not either curation or laboratory contamination.

\section{Results}

In total, 70 phytoliths, 9 starch granules or clusters, 3 pollen grains, and 13 miscellaneous microfossils were identified in the calculus samples from Nemrik 9 (Tables 2 and 3). Most phytoliths (c. $75 \%$ ) were recovered from calculus produced by only one individual $\mathrm{NK} / 2335$. Another relatively abundant context is NK/3341 (c. $20 \%$ ). Only two phytoliths were retrieved from other calculus samples. However, the two individuals with 
Table 2 Phytoliths retrieved from human dental calculus samples

\begin{tabular}{|c|c|c|c|c|c|c|}
\hline Grass & Phytolith type & $\mathrm{NK} / 2335$ & $\mathrm{NK} / 2393$ & $\mathrm{NK} / 2732$ & $\mathrm{NK} / 3341$ & Tota \\
\hline \multirow[t]{3}{*}{$\mathrm{C} 3$ grasses } & $\begin{array}{l}\text { Rondel-keeled } \\
\quad(\text { Pooideae })\end{array}$ & 9 & 1 & & 1 & 11 \\
\hline & $\begin{array}{l}\text { Rondel-pyramidal } \\
\quad(\text { Pooideae })\end{array}$ & 3 & & & 4 & 7 \\
\hline & $\begin{array}{l}\text { Trapeziform sinuate } \\
\quad(\text { Pooideae })\end{array}$ & 10 & & 1 & 3 & 14 \\
\hline \multirow[t]{3}{*}{ C4 grasses } & $\begin{array}{l}\text { Saddle } \\
\quad(\text { Chloridoideae })\end{array}$ & 1 & & & & 1 \\
\hline & $\begin{array}{l}\text { Bilobate } \\
\quad(\text { Panicoideae })\end{array}$ & 1 & & & & 1 \\
\hline & $\begin{array}{l}\text { Phragmites-type } \\
\text { rondel }\end{array}$ & & & & 1 & 1 \\
\hline \multirow{4}{*}{$\begin{array}{l}\text { Indeterminated } \\
\text { grasses }\end{array}$} & Buliform-cuneiform & 2 & & & & 2 \\
\hline & Elongate-smooth & 4 & & & & 4 \\
\hline & Elongate-spiny & & & & 1 & 1 \\
\hline & Trichome & 1 & & & & 1 \\
\hline \multirow{5}{*}{$\begin{array}{l}\text { Grass grain } \\
\text { indicators }\end{array}$} & Dendriform & 14 & & & 3 & 17 \\
\hline & Papillae & 2 & & & & 2 \\
\hline & $\begin{array}{l}\text { Dendritic } \\
\text { sheet element }\end{array}$ & 1 & & & 1 & 2 \\
\hline & $\begin{array}{l}\text { Wavy margin } \\
\text { sheet element }\end{array}$ & 5 & & & & 5 \\
\hline & $\begin{array}{l}\text { Triticum-type } \\
\text { sheet element }\end{array}$ & & & & 1 & 1 \\
\hline Total & & 53 & 1 & 1 & 15 & 70 \\
\hline
\end{tabular}

the largest calculus samples and highest phytolith yield represent two phases of occupation of the site, so temporal comparison is, to some extent, possible. On the other hand, other plant microfossils were distributed in a more uniform way.

Calculus sample NK/2335 included 53 taxonomically significant phytoliths. Of these, 31 appear to be derived from the surrounding environment when this individual was alive. Phytoliths ascribed to grass leaves are attributed to the local environment rather than suggesting people were eating grass leaves. Phytoliths from cool-season, $\mathrm{C}_{3}$ metabolism grasses (leaves) were dominant (22 in total). One saddle phytolith from the grass subfamily Chloridoideae was recovered, and one bilobate derived from the grass subfamily Panicoideae also was noted. Phytoliths likely associated with food consumption consisted of 14 disarticulated dendriforms (Fig. 2f), 2 papillae, 5 epidermal sheet element fragments with wavy-margined long cells (Fig. 2e), and a dendritic epidermal sheet element (Fig. 2g). None of these phytoliths exhibited characteristics that could be unambiguously ascribed to a particular grass. However, they are consistent with those found in husk material from wheat (Triticum sp.) and rye grass (Elymus sp., Lolium sp.).

Figure 2e shows a small sheet element fragment from a grass stem that has been cut with a threshing sledge. The four cuts on this phytolith include straight and slightly concave cut edges diagonally across the sheet element. Both are typical of

Table 3 Pollen, starch grains, and other microfossils retrieved from human dental calculus samples

\begin{tabular}{|c|c|c|c|c|c|c|c|c|c|c|c|}
\hline Fossils & Microfossil type & $\mathrm{NK} / 1891$ & $\mathrm{NK} / 2335$ & $\mathrm{NK} / 2393$ & $\mathrm{NK} / 2394$ & $\mathrm{NK} / 2423$ & $\mathrm{NK} / 2512$ & $\mathrm{NK} / 2638$ & $\mathrm{NK} / 2732$ & $\mathrm{NK} / 2801$ & Total \\
\hline \multirow[t]{3}{*}{ Pollen } & Cerealia pollen & 1 & & & & & & & & & 1 \\
\hline & cf. Brassicaceae & & & & & & & & 1 & & 1 \\
\hline & Cheno-am pollen & & & & & 1 & & & & & 1 \\
\hline \multirow[t]{2}{*}{ Starches } & Starch-angular & & & & & & & 1 & & & 1 \\
\hline & Starch-lenticular & 2 & & 1 & & 1 & 1 & 2 & & 1 & 8 \\
\hline \multirow[t]{3}{*}{ Miscellanea } & Fungal spores & 4 & 6 & & & 1 & & & & & 11 \\
\hline & Xylem fragments & & & & 1 & & & & & & 1 \\
\hline & Diatom-centric & & 1 & & & & & & & & 1 \\
\hline Total & & 7 & 7 & 1 & 1 & 3 & 1 & 3 & 1 & 1 & 25 \\
\hline
\end{tabular}




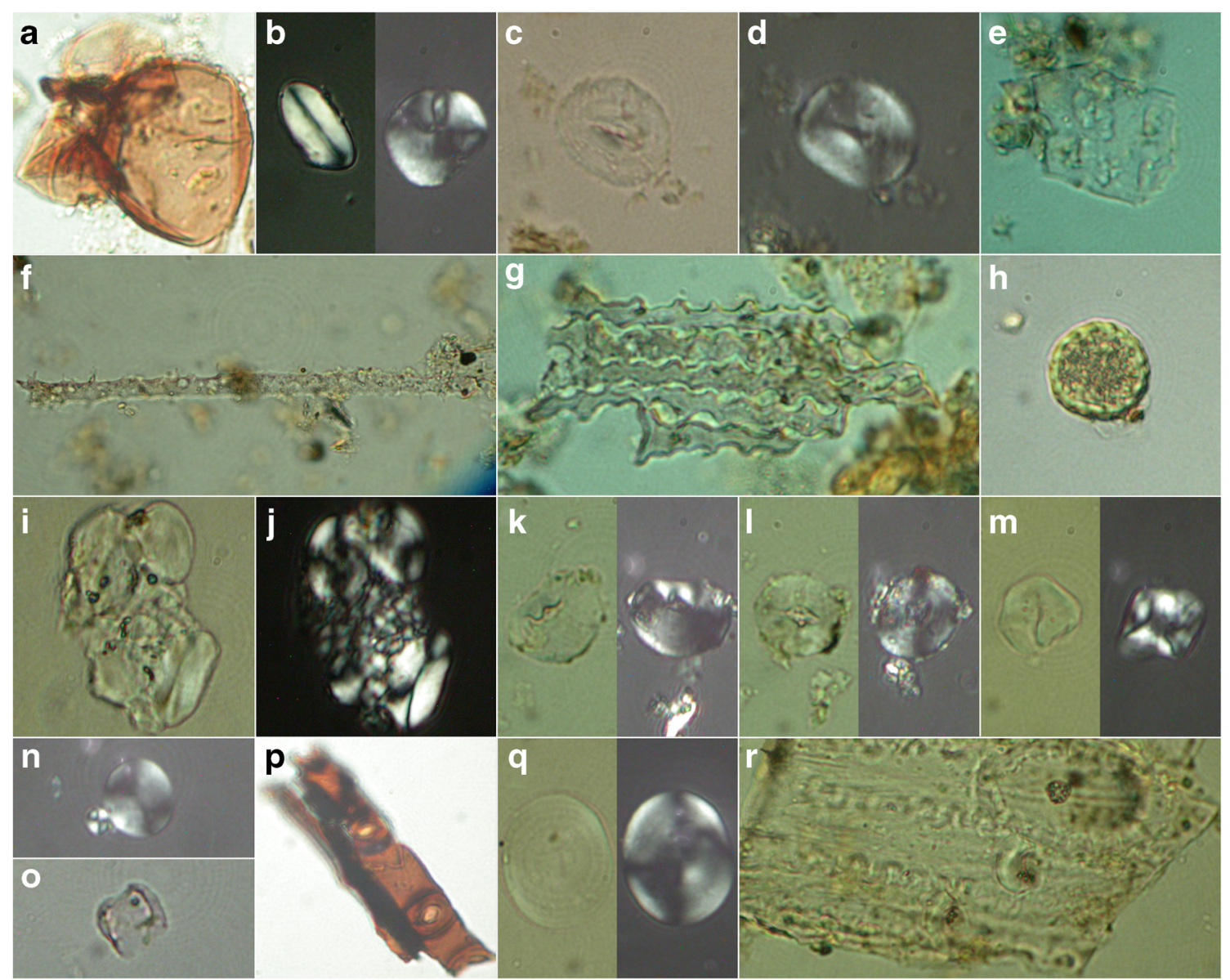

Fig. 2 Selected pollen, phytolith, and starch grain microfossils recovered from dental calculus samples from Nemrik 9. All micrographs were taken at $\times 500$ magnification. See text for individual descriptions

cuts produced experimentally when using a bladed threshing sledge (Anderson 1999). Both the length of the cut phytolith and the angle of the cuts are important. Longer pieces of stem are expected when the record is from harvested stems, while shorter pieces are typical of the repetitive cutting typical of threshing with a sledge. Cuts resulting from multiple passes of the sledge across stems, paleas, and lemmas produce many lengths of tissue containing silicified sheet elements. Cuts that are on a diagonal to the natural break between cells are more diagnostic of cutting with a sledge than are cuts along cell margins, whether they are along the long or short margins of the cell. Although it is theoretically possible to break sheets of silica along cells across the "tops" or "bottoms" of individual cells by trampling, these straight, perpendicular cuts are made by threshing sledges and considered to be typical of sledge use (Alkalesh and Anderson 2016). Cuts on the diagonal, on the other hand, cannot be argued to be natural, since there is no natural weakness to be exploited. Cuts perpendicular to the long axis of the cell may be the result of trampling or threshing sledge use, as hoofed animals treading on stems containing sheets of silica bodies might not only break the cells apart but might also break the cells in other ways. Experimental work with sickles, razors, scissors, knives, and other cutting tools produced jagged edges rather than smooth cut edges. Use of pressure when cutting does not produce a smooth cut edge. In contrast, when a threshing sledge "glides" on top of a thick layer or pile of straw, individual straws rotate under the threshing blades, scoring or cutting the straw rather than crushing it. Further, trampling by animals during the threshing process results in breaking down the straw fragments into ever-smaller pieces along the scored lines. In the absence of a threshing sledge, the same small size particles of straw have not been produced experimentally by trampling or any means of cutting.

Of the 15 phytoliths recovered from calculus sample NK/ 3341 , a total of 5 appear to be derived from glumes retained on cereal grains consumed by the individual, while the other 10 are most likely derived from the local vegetation growing during the time this individual was alive. The environmental signal was dominated by phytoliths derived from cool-season, $\mathrm{C}_{3}$ metabolism grasses. Only one $\mathrm{C}_{4}$ grass phytolith was observed, a saddle-type plateau (Fig. 2o) that is most likely derived from Phragmites. Of the five grass inflorescence phytoliths, three were disarticulated dendriforms, one was a small section of a dendritic sheet element, and one was a large 
fragment of a dendritic sheet element (Fig. 2r). Of particular interest was the large dendritic sheet with keeled rondels and single large papillae in situ. The long cell margins within this sheet element are of a wave pattern consistent with that of wheat (Triticum). The diameter of the papillae $(32 \mu \mathrm{m})$ and the height of the long cell wave patterns $(5 \mu \mathrm{m})$ are also within the range described for wheat and, most importantly, outside the range described for barley (Rosen 1992). Thus, this particular phytolith provides strong supporting evidence for the presence of wheat (Triticum) at this site. Distinction between wild wheat and domesticated wheat cannot be made using the wave pattern or papillae diameter.

Only two phytoliths were recovered from other calculus samples. One rondel phytolith was recovered from NK/ 2393, but it is impossible to determine if it was derived from the surrounding environment or was the result of grass seed consumption. Another phytolith was recovered from NK/ 2732, and it appears to be derived from the surrounding environment during the period of time when this individual was alive. This phytolith is a trapeziform sinuate common in leaf material from cool-season, $\mathrm{C}_{3}$ grasses.

Only a few pollen grains were recovered from tooth calculus at Nemrik 9. Sample NK/1891 contained a cluster of Cerealia pollen grains (Fig. 2a), and one cheno-am pollen (Fig. 2h) was included in the sample NK/2423. Finally, one Brassicaceae pollen was recovered from NK/2732, indicating local growth of plants in the mustard family and suggesting the possibility that a food was prepared from the mustard plant that was in flower.

Two clusters of starch grains were found in the samples from Nemrik 9. In sample NK/2393, a large cluster of lenticular starches (Fig. 2i, j) was observed that consisted of approximately 5 large grains (18-20 $\mu \mathrm{m}$ in diameter) and at least 14 small grains (2-4 $\mu \mathrm{m}$ in diameter). The characteristics exhibited by this cluster of starch suggest wheat, barley, or weedy goatgrass (Aegylops). In addition, two starch granules from $\mathrm{NK} / 2638$ are a small cluster of one large and one very small grain, with a few other very small particles adhering to the cluster (Fig. 2n). This type of appearance is consistent with experimental damage from parching (Henry et al. 2009), and this cluster may also derive from wheat or barley. Immature or small starches are not uncommon in reference material.

Other samples from Nemrik 9 contained only single starches. Three starch granules retrieved from NK/2638 are subangular and faceted and are consistent in shape and size with our references for starch produced in sorghum (Sorghum bicolor) seeds (Fig. 2m). Sorghum is not suggested as an identification due to the fact that it is not documented for this region prior to approximately 2000 BCE (Kimber 2000:15). These starches are, however, larger than those observed in millet. Additional reference work to compare starches produced in grasses native to the study area is necessary to identify native grass seeds that produce this morphology of starch.
In sample NK/1891, two starch granules (Fig. 2b-d) were observed. The starches were both lenticular in cross section and approximately $18 \mu \mathrm{m}$ in diameter. Both granules exhibited evidence of damage from cooking, most likely boiling, and as a result, these cannot be securely identified to genus. The cooking damage is fairly consistent with that typical for wheat (Triticum sp.); however, barley (Hordeum sp.) is a possible source for these grains as well.

Two starch grains from NK/2423 (Fig. 2k) and NK/2512 (Fig. 21) were circular in outline, lenticular in cross section, and exhibit damage from cooking that is consistent with boiling. Both granules appear to derive from either wheat or barley. One large, lenticular starch grain $(18 \times 22 \mu \mathrm{m}$ in diameter $)$ likely derived from wheat or barley (Fig. 2q) was recovered from sample NK/2801.

A few fungal spores not similar to yeast were observed in three samples, but they obviously represent diagenetic contamination of calculus. One darkened vessel element fragment with bordered pits, recovered from sample NK/2794 (Fig. 2p), was deemed quite unusual. This fragment might represent using a sliver of wood as a toothpick to clean the teeth. There is no evidence that the darkening is due to charring or burning. If, however, this fragment is charred or burned, then it is possible this fragment derives from a woody tree or shrub that was inadvertently consumed as wood ash from the cooking fire.

\section{Discussion}

The subsistence of Pre-Pottery Neolithic communities in the Fertile Crescent was based on wheat (especially einkorn and emmer) and barley (Willcox 2005), and this pattern is evident also in Nemrik 9, where most identified phytoliths and starch granules represent $\mathrm{C}_{3}$ cool-season cereals. The lenticular-shaped starches recovered in six of the contexts are consistent with consumption of wheat and/or barley. Cereal pollen was noted in one of the contexts $(\mathrm{NK} / 1891)$ that also yielded starch evidence for cereal (wheat or barley) consumption. The dendritic sheet elements, dendriform phytoliths, Triticum-type sheet elements, and papillae noted in contexts NK/2335 and NK/3341 provide additional evidence for consumption of cereals in samples that did not yield starch. The dendritic sheet element and papillae noted in sample NU/2335/C are typical of either wheat or rye grass, while the dendritic phytolith sheet element and papillae recovered in sample NU3341/C are typical of wheat.

Recovery of a phytolith sheet element displaying four cut edges that are diagonal to the long axis of the cells indicates the use of threshing sledge technology at Nemrik 9 during the lifetime of the individual NK/2335 whose remains were recovered from phase IVb and represented by this calculus.

Many starch grains retrieved from the available samples show damage that may have been induced by cooking. Clusters of starch grains can be an indication of parching (Henry et al. 
2009). Although some damage may be related also to diagenic factors (Collins and Copeland 2011), encapsulation of the starches and other botanic remains in dental calculus probably shielded them from a significant impact of diagenesis.

More interesting than the presence of $\mathrm{C}_{3}$ grass microfossils is the evidence of $\mathrm{C}_{4}$ warm-season grasses at Nemrik 9 , which was much less common. The phytolith representing Phragmites, identified in the sample of NK/3341, was most likely related to use of reeds available at the bank of the Tigris River as a raw material rather than a source of food. The distance between the site of Nemrik 9 and the river was only c. $2.5 \mathrm{~km}$, so riverine resources may have been easily exploited. There is no direct evidence of use of reed mats at Nemrik 9 (Kozłowski 2002), but mat remains or impressions were present at several other PPN sites in Mesopotamia (Akkermans and Schwartz 2003). Also, xylem fragments observed in the sample NK/2794 may be the result of using teeth as the "third hand" in processing of wooden tools or in basketry (see Molleson 2007 for evidence from Tell Abu Hureyra). Alternately, these xylem fragments might represent use of woody splinters as dental picks.

In total, only two phytoliths from warm-season, $\mathrm{C}_{4}$ metabolism grasses were observed, which probably represent grasses growing in the local vegetation community. One of them is typical of Chloridoideae, the subfamily of grasses that includes edible grasses such as lovegrass (Eragrostis sp.) and goosegrass (Eleusine sp.) (Glémin and Bataillon 2009). However, although many wild Chloridoideae taxa are present in the Near East (Nesbitt 2006), there is no evidence of domestication. If their grains or leaves were consumed, it likely would have been accidental when intermixed with wheat or barley.

The third $\mathrm{C}_{4}$ grass phytolith found at Nemrik 9 represents the subfamily Panicoideae, which includes several potentially edible grasses such as foxtail millet (Setaria italica) and sorghum. Actually, millet was never an important crop in Mesopotamia, although its grains were found at several PPN sites on the Euphrates, especially in Tell Abu Hureyra and Tell Mureybit (Hunt et al. 2008). Some grains of Panicoideae were observed in Jerf and Tell Qaramel farther east. Therefore, it is not possible to rule out the presence of millet (Willcox et al. 2008) as the origin of this phytolith. In all these other assemblages, however, millet was present in small relative quantities.

Sorghum was domesticated in Africa and there is no evidence of its introduction to Southwest Asia before the late fourth millennium BCE. The oldest sorghum grains found at archaeological sites of the Arabian Peninsula are dated to c. $3000 \mathrm{BCE}$, and this cereal was present only in the southern part of this region (Nesbitt 1993). During the third millennium $\mathrm{BCE}$, sorghum became quite common in India (Kimber 2000), but in Northern Mesopotamia, this crop appeared much later, as witnessed by a bas-relief in the Sennacherib's palace in Nineveh dated to c. 700 BCE (Vinall et al. 1936). The angular starch recovered from context $\mathrm{NK} / 2638$ is consistent in morphology with starches observed in our sorghum reference. It is, however, highly likely that local wild grasses should be considered as the origin for this starch grain. Until exhaustive comparison with starches produced in grass seeds native to the area is conducted, this starch cannot be assigned to any genus of grass. Recovery of a few phytoliths typical of tall grasses (Panicoideae) contributes to this discussion, suggesting the possibility that $\mathrm{C}_{4}$ grasses were consumed occasionally by PPN people from Nemrik 9. In this respect, this site did not differ from contemporary sites located in the Euphrates valley.

The few pollen grains retrieved from these calculus samples offer superficial insight into plants growing in the neighborhood of Nemrik 9. The Cerealia pollens are most expected, as grasses, either wild or already domesticated, were massively exploited by the local human group. The cheno-am pollen grain found in the NK/2423 sample represents a plant with edible leaves and seeds. Starches from most members of this group, which includes the Chenopodiaceae (goosefoot family) and the genus Amaranthus, are small and usually occur as relatively large clusters, when they are observed. This group of plants was exploited in North America (Delcourt and Delcourt 2004), but there is little indication that they may have been consumed in the Southwestern Asia (Blakelock 1957). Finally, Brassicaceae pollen suggests that mustard family plants were present in the neighborhood of Nemrik 9. Some Brassicaceae family members were present in Mesopotamia, and may have been used for oil, as suggested by evidence from third millennium BCE Khafajah (Bedigian and Harlan 1986), but there is no evidence of oil production in the PPN and the pollen may simply represent a weedy plant with no value for the local human group.

\section{Conclusion}

In spite of rather narrow evidence available in the present study, the research on plant microfossils embedded in human dental calculus from Nemrik 9 produced some interesting results. First, the consumption of $\mathrm{C}_{3}$ cereals, especially wheat and/or barley, has been confirmed by recovery of phytoliths and starches, although it is not clear whether they were already domesticated. Second, threshing is suggested by recovery of cut phytoliths. Third, the diet also may have contained small quantities of $\mathrm{C}_{4}$ cereals, either as unwanted contaminants in the $\mathrm{C}_{3}$ crops or as consciously gathered alternative resources. The necessity for further reference work is underscored by recovery of a subangular and faceted starch granule, consistent in morphology with sorghum, but likely also with wild grasses growing in the area. In the absence of a full list of grasses likely in the local environment and thorough examination of the starches produced in their seeds, it is not possible to associate this starch with any individual grass; therefore, further interpretation of its significance is not warranted. To the extent that reported remains from this study offer rather 
limited evidence, they signal the necessity of further reference work to create a library of starches for the region. Also, they open a discussion of introduction of threshing into the region. Recovery of these data creates a path for future discoveries that may aid in the discovery of technology associated with wild grass exploitation and the process of domestication.

Apart from insight into diet of an early farming community, some evidence of using plants as raw material also is apparent. The xylem fragments and Phragmites phytoliths indicate that wood and reeds may have been processed using teeth as a third hand. Alternatively, it is possible that either or both were used as dental picks to clean the teeth.

Acknowledgments We thank Amanda Henry and an anonymous reviewer for comments on the early version of the manuscript. The research was partially financed by the Polish Ministry of Science and Higher Education, grant no. N109 352236.

Open Access This article is distributed under the terms of the Creative Commons Attribution 4.0 International License (http:// creativecommons.org/licenses/by/4.0/), which permits unrestricted use, distribution, and reproduction in any medium, provided you give appropriate credit to the original author(s) and the source, provide a link to the Creative Commons license, and indicate if changes were made.

\section{References}

Akkermans PMMG (2003) The archaeology of Syria: from complex hunter-gatherers to early urban societies (c. 16,000-300 BC). Cambridge University Press, Cambridge, UK; New York

Alkalesh S, Anderson PC (2016) Identifying the Specific Action of the Threshing Sledge on Phytoliths in Cereal Straw: a quantitative study of experimental, ethnographical, and archaeological material. Poster presented at the 10th International Meeting of Phytolith Research, Aix en Provence, France

Anderson PC (1999) Experimental cultivation, harvest and threshing of wild cereals, their relevance for interpreting the use of Epipalaeolithic and Neolithic artifacts. In: Anderson PC (ed) Prehistory of agriculture. New experimental and ethnographic approaches. Institute of Archaeology, University of California, Los Angeles, pp. 118-139

Bedigian D, Harlan JR (1986) Evidence for cultivation of sesame in the ancient world. Econ Bot 40:137-154

Blakelock RA (1957) Notes on the flora of 'Iraq with keys - part IV. Kew Bull 12:461-497

Collins MJ, Copeland L (2011) Ancient starch: cooked or just old? Proc Natl Acad Sci 108:E145-E145

Crowther A, Haslam M, Oakden N et al (2014) Documenting contamination in ancient starch laboratories. J Archaeol Sci 49:90-104

Cummings LS, Magennis A (1997) A phytolith and starch record of food and grit in Mayan human tooth tartar. In: Pinilla A, Juan-Tresserras J, Machado MJ (eds) Estado actual de los estudios de fitolitos en suelos y plantas. CSIC, Madrid, pp. 211-218

Delcourt PA (2004) Prehistoric native Americans and ecological change: human ecosystems in eastern North America since the Pleistocene. Cambridge University Press, Cambridge [England]; New York, NY
Dudgeon JV, Tromp M (2012) Diet, geography and drinking water in Polynesia: microfossil research from archaeological human dental calculus, Rapa Nui (Easter Island): microfossils in dental calculus from Rapa Nui (Easter Island). Int J Osteoarchaeol. doi:10.1002/oa.2249

Glémin S, Bataillon T (2009) A comparative view of the evolution of grasses under domestication: Tansley review. New Phytol 183:273-290

Hardy K, Buckley S, Collins MJ et al (2012) Neanderthal medics? Evidence for food, cooking, and medicinal plants entrapped in dental calculus. Naturwissenschaften 99:617-626

Henry AG, Piperno DR (2008) Using plant microfossils from dental calculus to recover human diet: a case study from Tell al-Raqā' $i$, Syria. J Archaeol Sci 35:1943-1950

Henry AG, Hudson HF, Piperno DR (2009) Changes in starch grain morphologies from cooking. J Archaeol Sci 36:915-922

Henry AG, Brooks AS, Piperno DR (2011) Microfossils in calculus demonstrate consumption of plants and cooked foods in Neanderthal diets (Shanidar III, Iraq; Spy I and II, Belgium). Proc Natl Acad Sci 108:486-491

Henry AG, Brooks AS, Piperno DR (2014) Plant foods and the dietary ecology of Neanderthals and early modern humans. Journal of Human Evolution

Hunt HV, Vander Linden M, Liu X et al (2008) Millets across Eurasia: chronology and context of early records of the genera Panicum and Setaria from archaeological sites in the Old World. Veg Hist Archaeobotany 17:5-18

Kimber CT (2000) Origins of domesticated sorghum and its early diffusion to India and China. In: Sorghum: origin, history, technology, and production. Wiley, New York, pp. 3-98

Kozłowski SK (1989) Nemrik 9, a PPN Neolithic site in Northern Iraq. Paléorient 15:25-31

Kozłowski SK (2002) Nemrik. An aceramic village in northern Iraq. Instytut Archeologii UW, Warsaw

Mickleburgh HL, Pagán-Jiménez JR (2012) New insights into the consumption of maize and other food plants in the pre-Columbian Caribbean from starch grains trapped in human dental calculus. J Archaeol Sci 39:2468-2478

Molleson T (2007) A method for the study of activity related skeletal morphologies. Bioarchaeology of the Near East 1:5-33

Nesbitt M (1993) Archaeobotanical evidence for early Dilmun diet at Saar, Bahrain. Arab Archaeol Epigr 4:20-47

Nesbitt M (2006) Identification guide for Near Eastern grass seeds. Institute of Archaeology UCL, London

Piperno DR (1988) Phytolith analysis: an archaeological and geological perspective. Academic, San Diego

Rosen A (1992) Preliminary identification of silica skeletons from Near Eastern archaeological sites: an anatomical approach. In: Rapp, George J, Mulholland S (eds) Phytolith Systematics. Springer US, pp 129-147

Savard M, Nesbitt M, Gale R (2003) Archaeobotanical evidence for early Neolithic diet and subsistence at M'lefaat (Iraq). Paléorient 29:93-106

Savard M, Nesbitt M, Jones MK (2006) The role of wild grasses in subsistence and sedentism: new evidence from the northern Fertile Crescent. World Archaeol 38:179-196

Sołtysiak A, Wiercińska A, Kozłowski SK (2015) Human remains from Nemrik, Iraq. An insight into living conditions and burial customs in a Pre-Pottery Neolithic village. Paléorient 41:101-114

Torrence R, Barton H (eds) (2006) Ancient starch research. Left Coast Press, Walnut Creek, Calif

Tsartsidou G, Lev-Yadun S, Albert R-M et al (2007) The phytolith archaeological record: strengths and weaknesses evaluated based on a quantitative modern reference collection from Greece. J Archaeol Sci 34:1262-1275 
Vinall HN, Stephens JC, Martin JH (1936) Identification, history, and distribution of common sorghum varieties. United States Department of Agriculture, Washington DC

Willcox G (2005) The distribution, natural habitats and availability of wild cereals in relation to their domestication in the Near East: multiple events, multiple centres. Veg Hist Archaeobotany 14:534-541
Willcox G (2012) The beginnings of cereal cultivation and domestication in Southwest Asia. In: A companion to the archaeology of the ancient Near East. Blackwell Publishing, Oxford, pp. 163-180

Willcox G, Fornite S, Herveux L (2008) Early Holocene cultivation before domestication in northern Syria. Veg Hist Archaeobotany 17: $313-325$ 